\title{
Science and Religion: An Alternative View of an Ancient Rivalry
}

\author{
Shane Andre \\ California State University, Long Beach, USA \\ Email: sandre20@roadrunner.com
}

How to cite this paper: Andre, S. (2020). Science and Religion: An Alternative View of an Ancient Rivalry. Open Journal of Philosophy, 10, 494-510. https://doi.org/10.4236/ojpp.2020.104035

Received: July 8, 2020

Accepted: November 14, 2020

Published: November 17, 2020

Copyright ( 2020 by author(s) and Scientific Research Publishing Inc. This work is licensed under the Creative Commons Attribution International License (CC BY 4.0).

http://creativecommons.org/licenses/by/4.0/

\begin{abstract}
Religion is presented as a family of religions, identified by a cluster of religion-making features, most but not all of which must be present, involving beliefs and practices which are diverse and often in conflict. Because of differences in scope, application of scientific method, and vocabulary, science can also be regarded as a family-this time a family of sciences. The universality of the physical sciences contrasts with the more restricted scope of the earth sciences and the human sciences. Their relationship can be shown by a three-tiered pyramid, with the physical sciences at the base, the human sciences at the top, and the earth sciences in the middle. Despite three notable differences between science and religion, science and religion are not, as popularly believed, in conflict. The contrary view, espoused by the "new atheists," is shown to be based on oversimplified views of religion and science. There are nontheistic religions and science is committed, not to metaphysical naturalism ("scientism"), but only to methodological naturalism. Stephen Jay Gould escapes the conflict view by proposing that science and religion are independent "magisteria", science being occupied with facts and religion with values. In divorcing the realm of facts from the realm of values, he too distorts their complex nature, for science is not devoid of values and religion makes claims about the facts. As Hume long ago suggested, facts and values are interconnected. While a fact is not the same as a value, a fact cannot support a value without presupposing another value in turn. Interaction between facts and values is here to stay.
\end{abstract}

\section{Keywords}

Religion-Making Features, Non-Theistic Religions, Diversity of Religion, Unity and Diversity of Science, Science and Math, Science and Technology, Metaphysical Naturalism, Methodological Naturalism, Science and History, NOMA-Principle, Facts and Values 


\section{Introduction}

Thanks to the popular writings of the "new atheists", many people have come to think of science and religion as two monoliths between which we have to choose, or at best as two "magisteria" standing in lordly independence from one another, in the manner suggested by Stephen Jay Gould.

I will argue that both views are mistaken and spring from an impoverished understanding of their subject-matter. The conflict view treats religion as if it were identical with monotheism, but a survey of the world's major religions shows that, on the contrary, there are many religions and that they are remarkably diverse. Not all are monotheistic, or even theistic. It also suggests a simplistic view of science. While science can be said to be the study of nature, nature as a whole is too large and too complex to be the object of single-minded study. Instead, we study the significant parts of nature and in so doing create a host of highly specialized sciences, from physics to linguistics.

While Gould's view removes the conflict, it attaches to religion the idea that its exclusive concern is with values and optimizing the meaning of life. This idea is faulty on two scores. First, important as values are in religion, they have long been the concern of other disciplines, including normative ethics and moral psychology. Second, as its literature shows, religion is no less concerned with the nature of reality than it is with the nature of morality, and for understandable reasons. As Hume famously suggested in his Treatise, values and facts are interconnected, which renders absurd the idea of treating values as if they were a separate domain. To paraphrase a famous observation by Einstein, facts without values are lame (why should we care about the facts?), and values without facts are blind (why these values and not others?). For human life to be meaningful it is imperative to develop a coherent set of values within the constraint of the best available information about the world.

\section{Religion: A Family-Resemblance Model}

In thinking about religion, we want to avoid the comic mistake of the Reverend Thwackum, parodied by Henry Fielding in his novel Tom Jones. This is the fallacy of defining religion in terms that are true, at most, of one particular religion. "When I mention religion", the Reverend says, "I mean the Christian religion; and not only the Christian religion, but the Protestant religion; and not only the Protestant religion but the Church of England” (Fielding, 1749, 1980: p. 211). Ergo, religion is the Church of England. The mistake is easy to see but hard to avoid. The Church of England is a religion, not religion. Even Christianity is a religion, or, better, a set of religions and the same thing is true of Judaism and Islam. Religion cannot be defined as belief in God, for there are polytheistic religions like Hinduism and godless religions like Theraveda Buddhism. Spinoza proposed a philosophical religion, identifying God and nature as different aspects of what is essentially one, today known as pantheism. Theologian Paul Tillich spoke of religion as "faith in ultimate concern" (Tillich, 1957, 2001: p. 7). 
To deal with this multitude, William Alston, writing on religion in the Encyclopedia of Philosophy (Edwards, 1967), took a cue from Wittgenstein's conception of a family resemblance term (Wittgenstein, 1953: sections 67-68). He defined religion in terms of a cluster of nine "religion-making characteristics" which may, but need not all, be present for something to count as a religion:

Belief in a supernatural being or beings (gods).

A distinction between sacred and profane objects.

Ritual acts focused on sacred objects.

A moral code believed to be sanctioned by gods.

Characteristically religious feelings (awe, sense of mystery, sense of guilt, adoration, which tend to be aroused in the presence of sacred objects and during the practice of ritual, and which are connected in idea with gods).

Prayer and other forms of communication with gods.

A world view, or general picture of the world as a whole, including one's place in it. This picture contains some specification of an over-all purpose or point of view of the world and an indication of how the individual fits into it.

A more or less total organization of one's life based on this world view.

A social group bound together by the above.

Far from being just a matter of belief, religion includes a cluster of other special features, including emotions, rituals, social practices, and moral codes.

No doubt there are variations here, especially between theistic religions like Christianity, which envisage divinity outside the world, and nontheistic religions like Buddhism which find divinity within the world. Whereas the former is more exemplary of religion, because they exhibit all of these features, the latter are still examples of religion, because they satisfy enough of them. The boundaries of religion are broad enough to include, not just varieties of theism, but also varieties of nontheistic religions, like Taoism and Confucianism, according to Huston Smith's well-known study (Smith, 1958).

Instead of defining religion in terms of organized religions, Ninian Smart, possibly the preeminent scholar of religious studies in English in the twentieth century, takes a different tack. In his Smart, 1989, he proposes a seven-part "scheme of study" for the subject. It includes the practical and ritual, the experiential and emotional, the mythic or narrative ("the story side of religion"), the doctrinal and philosophical, the ethical and the legal, the social and the institutional, and the material (buildings, artifacts, etc.) As he says (p. 12),

Though we use the singular label "Christianity," in fact there are a great many varieties of Christianity, and there are movements about which we may have doubt as to whether they count as Christian. The same is true of all traditions: they manifest themselves as a loosely held-together family of subtraditions.

The moral to be drawn from these scholars is that religions without gods are still religions, even if religions with gods are more exemplary of that category. By analogy, when people think of birds, a robin is more exemplary than a penguin or ostrich, but that doesn't mean that the latter are not birds. In The World Until 
Yesterday, Jared Diamond (2012) points out that the preoccupation with religion as a separate category is a modern development, not shared by earlier societies, which did not distinguish religion from its other activities.

Just as language is a family of languages, it is possible to think of religion as a family of religions. Where the relationship is close, as it is for some forms of Protestantism, we may prefer to speak of denominations, but the spread between Roman Catholicism and Protestantism seems to be large enough to call them separate religions. In any case, the spread between the world's major religions is wide, and that between the theistic and nontheistic varieties is even wider. The parallel with language-families like Indo-European and Sino-Tibetan comes to mind. Members of the family of religions are no less diverse than the languages they speak.

Like human families, its members are often fractious and squabble with one another in great events like the crusades and the inquisition. Some of its members even quarrel with science itself, as shown by the Church's opposition to Galileo's defense of the heliocentric theory and the creationist attack on the teaching of evolution in public schools. If you identify religion with movements like these, you will undoubtedly see religion as the enemy of science and progress. But that is the Thwackum fallacy all over again. The adherents of a particular faith may be at war with science but that doesn't mean that religion is at war with science. Indeed, many reputable scientists are self-confessed believers, as is Francis S. Collins (2006), author of The Language of God: A Scientist Presents Evidence for Belief as well as leader of the human genome project and later head of the NIH.

\section{A New Perspective on Science}

In contrast to the idea of many religions, people tend to think of science as a single-minded enterprise, pursued by a common method, and leading to uniform results. If they are sophisticated, they may realize that in fact science consists of many fields or branches: after all, the study of physics is not the same as the study of biology or psychology. But the absence of overt friction between them, apart perhaps for public funding, makes it easy to presume that they are "one." The truth, however, is more complex. Science can be regarded as a family of sciences, like the family of religions, except that its members are united by a single aim: understanding the natural world by experiential means. The common task of the sciences is to break up the study of what is given to us by nature into accessible parcels ("carving nature at the joints"). This task is often called the project of methodological naturalism: describing nature by the means that it supplies: the use of our senses and natural faculties, along with their extension by specialized instruments and the use of cognitive tools like mathematics. Despite this common aim, the study of matter is not the same as the study of living matter or the study of intelligent matter. For, while the latter studies must be consonant with the former, it does not follow that they can be reduced to it. Arguably, 
physics is more fundamental than biology or psychology, but the net of physics doesn't capture all the fish in the sea.

As far as vaunted scientific method goes, it can be described in very general terms as a mix of observation, measurement, proposed explanatory hypotheses, testable predictions, confirmation or its opposite, and review and replicability, but it is practiced very differently in physics than in (say) psychology. The results of these practices may require very different procedures and vocabularies, so that familiarity with one science does not guarantee familiarity with others. A person would have to be very naïve to suppose that learning about human psychology would equip him to understand the abstractions of physics. It is safe to say, however, that a psychological hypothesis that flew in the face of our best understanding of biology or physics would be, for that very reason, highly suspect.

Depending on the scope of their study, we can distinguish three major groups of scientific activity. First and foremost are the physical sciences, whose scope is the universe as a whole: physics, astronomy, cosmology, and chemistry. Astronomy and astrophysics, as their names imply, are classic examples of the broad sweep of this group of sciences. Physics endeavors to tell us about matter and energy, not just in our terrestrial environment, but anywhere in the universe. Thanks to its study of the elements, chemistry can now put to rest the complaint of Auguste Comte that man will never know the composition of the stars (Hearnshaw, 2010).

Second are those sciences which could be called earth sciences, for they focus on special features of our planet: biology, paleontology, geology, oceanography, and meteorology. While some features of our home planet are shared by other planets, we do not know whether this is true of other features, like the presence of intelligent life. Despite SETI-the search for extraterrestrial intelligent life-intelligent life could be a unique feature of Earth. This seems to have been Pascal's view of man: "Man is only a reed, the weakest thing in nature; but he is a thinking reed". Pascal took for granted that this reed was alone in the universe. In contrast, many scientists now take panspermia and the evolutionary process for granted: given the right natural conditions, simple living organisms will emerge and, with sufficient time, evolve into complex varieties of life.

Third is that cluster of sciences which, for want of a better name, we could call the human sciences because they focus on our species: anthropology, archaeology, sociology, psychology, economics, and linguistics. The narrow but richly detailed focus of the human sciences contrasts with the broad but less intimate focus of the physical sciences, in a way that invites the analogy between the map of a city (the human sciences) and the map of the world (the physical sciences). Changes of scale bring new worlds into view. For physics, fair reader, you are just another hunk of matter; for chemistry, a bag of chemicals; for biology, an animal of the species Homo sapiens, for psychology, a male or female of a certain age and profile. Each level hives off certain features, the objects of its special 
attention, and ignores others, which figure only in the background. Those mentioned are all at the third-person level; we have not met you, and perhaps never will, at the first-person or subjective level, the level of your perceptions, thoughts, and feelings. The scope of our subject shrinks as we narrow our field of view, but at the same time, it brings to light new phenomena in greater depth and richness of detail.

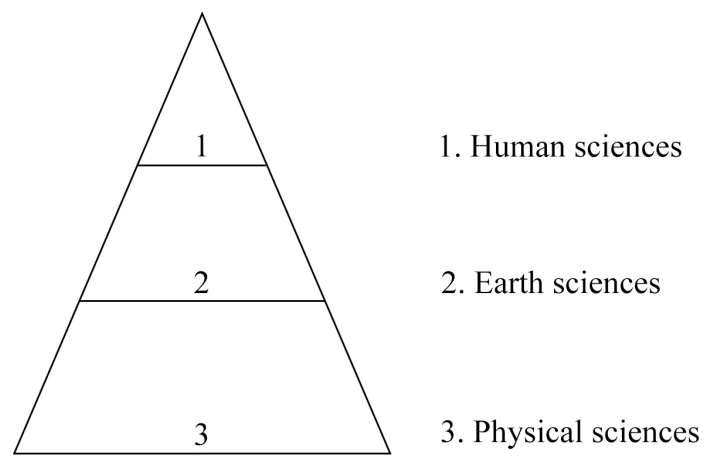

Science: The Pyramid of Sciences (The diagram is not intended to suggest that the human sciences are "higher" or "more worthy" than those below. On the contrary, since the physical sciences, especially physics, set the framework for the other sciences, they are "supreme").

Two objections to this sketch are worth addressing. First, as already noted, we often speak of fields or branches of science rather than of multiple sciences. True, speaking of fields or branches may reduce the impression of diversity, but the diversity is there. The study of the physical sciences is very different from what I call the human sciences; some scientists even question whether the latter are genuine sciences. We have a situation analogous to that of religion. Some people but not others are inclined to deny that nontheistic religions are truly religions, just as some deny that psychology is truly a science.

The issue should not be decided by fiat. As Charles Darwin (Darwin, 1857) suggested, there are alternative ways of describing the same class of things. Splitters prefer a narrower, lumpers a broader, conception of a subject-matter. What is a matter of choice allows either party to speak as they choose. The important thing is to understand, not to legislate, usage. I see no harm in speaking of psychology as a science, as long as we bear in mind that its subject-matter and its application of scientific method are different in scope and detail from that of physics but suitable for its own type of investigation. The same point goes for the larger topic of science itself. Impressed by its methodological naturalism, we may be tempted to think of it as a monolith, but at the same time, we should never overlook the diversity of its broad subject matter-a perspective which enables us to view science as a family of sciences. That does not mean it is wrong to speak of science in the singular (e.g., "science today was once known as natural philosophy"), where the intended reference is all recognized sciences, any more than it is wrong to speak of language in the singular, when the intended 
reference is all recognized human languages.

The second objection has to do with the delineation of the sciences. Astronomy by all accounts is a science, but is cosmology, the study of the history of the universe, a separate science or only a branch of astronomy? A similar question can be asked about anthropology and archeology. I hold no brief on questions of this sort, important as they are for many specialists. While there is room on my provisional list for additions and/or deletions, there clearly is a difference between the study of features of the universe as a whole and the study of its focal parts. Given this difference, it is not surprising that mathematics plays a major role in the physical sciences but less so in those sciences which call for intensive field investigation.

The plurality of sciences resembles the plurality of religions, but there are three important differences. First, the family of sciences is compatible with each other in a way that is not true of the family of religions. At crucial points Christianity wars with Islam and Buddhism, but astronomy does not war with biology or sociology. The sciences can be represented on a three-tiered pyramid, with physical sciences on the bottom, human sciences on the top, and earth sciences in the middle. Their mutual coherence helps to explain why people tend to see the sciences as one and to repose greater confidence in them than in religion. As far as I can see, no such pyramid is possible for the world's major religions. We can think of the family of sciences as exhibiting unity in diversity, unlike the family of religions which notoriously exhibit diversity without unity.

Second, there is the matter of methodology. While science is associated with the scientific method, there is no such thing as the "religious method." Believers often speak of "faith" but it is often faith in the deliverances of one or more informal ways of supporting belief. These ways include revelation (testimony as to God's word); historical evidence (fulfillment of prophecies and performance of miracles); religious experience (the experience of conversion and feelings of awe and dependence); the need for morality (allegedly absent in a godless world); and reason (the argument from design and many others). This is merely a sketch, and it takes no stand on whether any of these ways can properly be called methods. The point is not that religion has its own methods, but that religious beliefs have been, and are, backed up in ways that for the most part are foreign to scientific practice.

Finally, there is the question of moral guidance. Traditionally, this task has fallen to the lot of religion and sometimes to moral philosophy, but not to science. Scientists offer no injunctions of the form "Thou shalt not take human life", not because they are, as human beings, indifferent to morality, but because their field of expertise gives them no special insight into this domain. Behavioral scientists can, of course, study the behavior of people who violate social norms, offer hypotheses about the causes of such behavior and its typical outcomes ("crime doesn't pay"), but it is not their job, as scientists, to offer moral instruction. If an eminent scientist were to proclaim on TV, "Taking innocent human 
life is wrong", he would be understood by viewers as expressing his private moral convictions, not as an expert on morality. (Are there such experts?) Yes, people sometimes make use of science to give weight to their moral pronouncements-"Science says that smoking is bad for you"-but science itself is not in the business of telling people what to do. As far as science goes, you can smoke if immediate gratification means more to you at this time than its long-term health impact (Hempel, 1988: pp. 334-348).

Science, as sketched above, needs to be distinguished from two adjacent areas: technology and mathematics. Technology can be regarded as the application of basic scientific knowledge to serve human ends, which range across the board from life-saving measures to weapons of mass destruction. To some thinkers, technology holds the promise of utopia, including the abolition of suffering and the inevitability of death, and to others, it threatens the survival of our species. Technology is the business end of science, and advances in technology help to explain why science is popular with the public. Many people see no need to distinguish between science and technology but surely there is a difference between knowing that water expands when it freezes and knowing how to build a refrigerator. People have known the former since ancient times, but no one knew how to do the latter until the nineteenth century.

Mathematics, on the other hand, is another story. While it is valued as an essential tool in scientific practice, it has long been known to be an independent science, based on a priori reflection rather than empirical investigation and discovery. For example, once we learn that any number can be increased by the addition of one, we can easily infer that the number of numbers must be infinite. It would be naïve to suppose that we discover this fact by the use of scientific method.

It should be clear by now how science and religion are similar in some respects but not in others. Given these complex relations, it makes no sense to say that they are friends or foes. Religion as such is not incompatible with science, though some religions are, and many religions are incompatible with each other. There are religious wars but no science wars in which a recognized science $X$ wars with another recognized science $\mathrm{Y}$, though of course there are disputes about science matters and real wars that make use of science. Einstein, who had much to say about both domains, seemed to think that science and religion were complementary. "Science without religion is lame", he observed, "religion without science is blind" (Einstein, 1941). Einstein may have looked to religion for something he could not find in science-moral guidance.

\section{Science and the New Atheism}

The new atheists-usually identified as evolutionist Richard Dawkins (2006), neurologist Sam Harris (2004), journalist Christopher Hitchens (2007), and philosopher Daniel Dennett (2006)-have each written full-length works in which they take for granted that science and religion are in conflict. As they see it, re- 
ligion is faith-based belief in the primacy of the supernatural realm, whereas science is evidence-based belief in the only world there is-the natural world. Given their assumptions, it is hard to quarrel with their conclusion, but there is no need to make such a gift, for their assumptions are highly questionable.

The new atheists speak of religion as if were identical with theism: belief in one or more supernatural beings who bear a superficial resemblance to human beings but vastly exceed them in power, knowledge, and benevolence or malevolence. While it is true that many people think of religion in those terms, a broad view of religion, such as we find in Alston and other scholars, does not support this outlook. To fail to see that religion can take non-theistic forms is another manifestation of the Reverend Thwackum fallacy. Despite his prominence as a Christian philosopher, Alston found it necessary, as we have seen, to endorse an approach to religion that did not tie it to the apron strings of theism. Ninian Smart (1989) and Huston Smith (1958) are other scholars who separate the study of religion from the study of theology and celebrate the diversity and plurality of religious traditions. That is not to deny the possibility of stipulating that nothing counts as a religion unless it involves belief in a supreme being, but, as Bertrand Russell said (Russell, 2019): "The method of 'postulating' what we want has many advantages: they are the same as the advantages of theft over honest toil".

Is it true that religion, unlike science, is no more than faith-based belief? No doubt faith plays a more prominent role in religion than in science, but, as we already noted, it can take the form of faith in a variety of sources, including some that are not confined to religion, like history, reason, and experience. In my view, none of these sources yield unequivocal support for theistic belief. But it is tendentious to imply, as atheists often do, that theists draw no distinction between blind faith and faith that looks for support outside the individual's state of mind. Evidence-based as it is, it is doubtful whether science itself can altogether escape some element of faith: apart from "animal faith" (Santayana, 1923, 1955), can you be sure that the pursuit of science will work as well in the future as it has worked in the past? The problem of induction aside, what if it led to nuclear war or Greenhouse Earth and the demise of civilization?

In their opposition to religion, the new atheists seem to take for granted that the only things which exist and of which knowledge is possible are the objects within the purview of science. Call these natural objects. Since gods, demons, souls, and their like are not natural objects, it follows therefrom that they cannot exist and that, while belief in them is possible, none of it can rise to the level of knowledge. Embedded in this position, therefore, are profound negative metaphysical and epistemological implications, to the effect that "Nature is all there is", a doctrine known as "metaphysical naturalism" or colloquially as "scientism".

I would like to make two points about scientism. First, as far as I can see, scientism may well be true. Science has made great strides in explaining a wide variety of natural phenomena, some of which had long evaded its grasp. Meanwhile, the opponents of scientism continue to quarrel amongst themselves, 
without any end in sight. In some cases, the absence of probative evidence for something is evidence of its absence, and this may be one of them. Whether scientism is true, however, is not the point. The point is whether science, as we know it today, entitles us to draw such sweeping conclusions. That case remains to be made.

My second point is that scientism is not the same as methodological naturalism, the framework of science. The latter counsels scientists to investigate nature by natural (i.e., experiential) means. It does not counsel them to ignore anything that cannot be investigated in this way. Mathematics is the striking example of a discipline which floats free from the tribunal of experience. If one discipline can escape this taskmaster, there is no a priori reason why it alone can do so.

While this point is often overlooked, mathematics like philosophy is another arm-chair discipline. Only those who do not engage fully with these subjects would condemn them for that reason. At high levels of abstraction mind-work can be no less demanding than experimental work in the lab or investigative work in the field. While it nowhere achieves the rigor and consensus amongst its practitioners as is found in math (but not the philosophy of math), philosophy can be described as a discipline whose practitioners aspire to the a priori state of their discipline.

This aspiration is exemplified in the Cartesian program (Descartes, 1641, 1984a) to reform the structure of human knowledge on the basis of the cogito and the conjecture that God is no deceiver. Yes, the failure of that program casts doubt on the project, but another in the twentieth century might take its place-the analysis of the fundamental concepts that occur repeatedly in science, philosophy, and common life, like "causation", "law of nature", "truth", "knowledge", "mind", "free will", and the like. As yet a work in progress, conceptual studies await a final verdict. In the meantime, it appears that concepts, numbers, and other intellectual products are abstract objects and not natural ones. The relation between the abstract and the a priori calls for further investigation, beyond the bounds of this paper.

History in its various forms is another discipline where scientism may come up short. As a record of particular persons and events in the past, it is questionable whether that record can, even in principle, be derived from the general form of the laws of nature. For example, we know a great deal about the life of a particular statesman-say, Winston Churchill-but how could that knowledge be derived in its countless details just from the science of psychology, sociology, or other scientific discipline? If the other sciences cannot be reduced to physics, we should not be surprised to find that history cannot be reduced to science either.

Two further reasons can be given for highlighting the distinctive role of history. First, history is notoriously vulnerable to diverse interpretations of the events it records. Japanese and American historians can be expected to offer very different accounts of the Second World War, without either departing radically from the facts. Since the sciences themselves have their own individual histories 
of development-the physical sciences were the first to break away from natural philosophy - they cannot dispense with their place in the record of the past. No doubt science can have a role in historical investigation-if nobody can be raised from the dead, then the story of the revival of Lazarus must be a myth-but that is not sufficient to make history a science. Compare: scientific investigation has a role to play in verifying the authenticity of works of art, but that doesn't make art a science.

Finally, historical events are in large measure subject to contingency or chance. Events that are very probable do not always occur, and the improbable occurs instead. No better example can be found than the tragic one of Claus von Stauffenberg (Shirer, 1960: p. 1027ff.). Stauffenberg was a German army officer who on July 20, 1944 attempted to assassinate Hitler by placing a time bomb hidden in a briefcase near his feet. The bomb exploded but, improbably, Hitler survived with only minor injuries, and the Nazi party continued in power until the following year. But Stauffenberg and many others judged to be complicit in the crime were executed. Whether we expect it or not, history can take strange turns. Who could have predicted the assassination of President John F. Kennedy on November 22, 1963? Science, no less than the man on the street, is often blind to the course of events.

Since history is not a science, it is hard to see how scientism can accomplish its ambitious goal. While it aspires to speak with the authority of science, it makes commitments that are more philosophical than scientific. Science is committed to no more than methodological naturalism. This form of naturalism is committed to the reality of the natural world and our access to it, without insisting that nature, as depicted by science today, is all there is. As Hamlet tells Horatio, "There are more things in heaven and earth/Than are dreamt of in your philosophy." Scientists have confirmed this observation many times in the last hundred years. Who would have guessed that there are billions of galaxies beyond the Milky Way, that black holes are found at the center of galaxies, that the universe itself began in a kind of violent explosion?

As for the new atheists, they would do well to rest content with the virtues of methodological naturalism and to temper their animosity to religion. Even if a supernatural being is not needed to explain the wonders of astronomy, as Laplace is reported to have said to Napoleon, the idea of a God who favors Roman Catholics and creates the world ex nihilo is not the whole story. Human beings have crafted a multitude of other ideas about the divine and it doesn't follow that none of these ideas has a footing in reality. For this reason, if no other, we can speculate that the "wise man" who proportions belief to the evidence (Hume, 1748: p. 653) would not be inclined to be a doctrinaire theist or a positive atheist (Andre, 1993: pp. 141-142).

\section{NOMA to the Rescue?}

In one of his last works, Rocks of Ages: Science and Religion in the Fulness of 
Life (Gould, 1999) Stephen Jay Gould proposes an alternative to the conflict model by giving science and religion different jobs to do. Accounting for his title, he mentions the cliché about science studying the age of rocks and religion the rock of ages (p. 6). This of course is a metaphor but he unpacks it with an interesting claim. Borrowing the theological concept of a "magisterium"-a self-standing discipline which has its own problems and ways of dealing with them-Gould claims that science and religion are independent magisteria. The job of science is, by means of scientific method, to discover what is true of the natural world, and the job of religion is, by its own means, to articulate and defend those values in terms of which human beings can lead meaningful lives. $\mathrm{He}$ calls this principle NOMA (p. 5), short for "Non-Overlapping Magisteria." (Not to be confused with the similar sounding "majesteria").

This is an interesting proposal that is not without merit. It was anticipated by Galileo, whom Gould quotes, who said that astronomy teaches us about the heavens but religion teaches us how to get to heaven. Asked why heavy airplanes are capable of flight, it would be natural to turn to science; asked why we should not return injury for injury, it would be equally natural to say "It says so in the Gospels" or "Two wrongs don't make a right" or "An eye for an eye makes the whole world blind”. In Gould's view, science deals with facts, religion with values.

But this view of science and religion is overly simplistic. The pursuit of science has its own values-coherence, reliability, simplicity, fruitfulness, etc. We could account for a miracle as the intervention of the divine spirit in the regular cycles of human life, but, as Hume argued in his essay on miracles (Hume, 1748), it is more probable that the report of a miracle is the result of mistake or deception, than that someone has witnessed the violation of a long-attested law of nature. The argument is controversial but it reflects a model of scientific thinking: this hypothesis is more probable than that one, so the wise man will accord the first greater credibility, until a better one comes along. Hume could also have said that his hypothesis is the simpler of the two, for it needs no ad hoc assumption about divine intervention. The emphasis on probability, simplicity, and the willingness to revise one's judgments in the light of new evidence is characteristic of science. Values are present in this model of thinking about the facts. Other things equal, we generally prefer the more probable or simpler hypothesis as more likely to be true. Once having settled on a hypothesis we could hold on to it come what may, but instead we prefer to revise or abandon it in the face of clear counterevidence.

If epistemic values play a role in our conception of facts, facts also play a role in our conception of values. If people turn to the Gospels for insight, it is because they see something special there: the word of God, psychological insight into human reactions, the distillation of common experience, or what have you. The idea of not returning evil for evil is so surprising to many people that they naturally ask "Why not?" As we have seen, a variety of reasons can be offered in reply, but they all purport to be relevant and factual. The reply "I have no rea- 
son" or "I just think so" or "Timbuktu is in Africa" would be unintelligible.

Paradoxically, Gould assigns to religion a task that is commonly assigned to philosophy today: the task of identifying good and evil, right and wrong, duties and rights, and other normative questions. However, in earlier times one of the central tasks of religion was to act as a moral guide, policeman, and judge. The promise of heaven and the threat of hell were held out as inducements to proper behavior. Even today there appear to be millions of believers who take these inducements seriously enough to govern their behavior, and to impose its rules on others. Secular minds may scoff at such notions as medieval superstition, but if they do, that is only because they no longer take it seriously.

Though religion has often been regarded as the guardian of public morality, when we look at the history of many religions, it is not clear that it deserves that title. Differences of religious belief and practice have often been associated with discrimination, persecution, violence, terrorism, and war. As Steven Weinberg said, "With or without religion, good people can behave well and bad people can do evil; but for good people to do evil-that takes religion" (Weinberg, 1999, 2001: p. 242). It is surprising that, in placing religion on a level with science, Gould has little to say about the dark side of the history of religion. While acknowledging that men have done evil in the name of organized religion, he dismisses further discussion of the point by attributing such evil, not to religion, but to the confluence of religion with secular power (Gould, 1999: p. 9). He does not consider the possibility that, in reposing so much confidence in faith, religion encourages its followers to exalt their faith over that of others. The exclusivism of organized religion is surely a serious matter.

Gould is right to recognize the equal importance of facts and values, but, in assigning them to different magisteria, he leaves it unclear how they can work together. And they must work together, as Hume suggests, for values are justified by their connection to facts (Hume, 1739-1740, 2006). For example, when a teacher admonishes his students "You ought to work harder" (value), he takes for granted, and hopes they will too, that working harder is in their long-term interest (fact), and that they ought to pursue what is in their long-term interest (value). A similar view of Hume's contribution has been supported by Ronald Dworkin (2011), philosopher of jurisprudence, in his recent book, Justice for Hedgehogs.

When the reasoning is fully spelled out, notice that the fact is sandwiched between a pair of related values, the implicit one being usually more general than the stated one, in a form of logic known as the enthymeme. Being implicit, the unstated premise is easily missed or taken for granted in a simplified form, This is unfortunate, for the implicit premise may be subject to recognized exceptions. For example, when parents counsel their youngster, "You ought not to lie, because if you do, you'll never be trusted", they may have in mind, not the unqualified "It is always wrong to lie", but something more thoughtful, like "It is always wrong to lie, except where telling the truth would cause people more harm than good". 
It is true that there is no unique principle of practical deliberation. Since enthymemes can often be completed in more than one way and still be valid, this openness to interpretation may be one reason for the supply of divergent moral principles on offer. Ethics, like religion, has its own problems with competing intuitions.

While Hume's after-thought about the "is/ought" transition is hardly the last word on the subject, it does suggest that the contrast between values and facts is overdrawn. Take away the values and the fact, if that is what it is, loses its interest. The idea that facts reside in one sphere and values in another would have struck Hume as absurd.

To sum up this assessment of NOMA, Gould was right to think that the task of religion included engaging with values, but wrong to think that this was its only task or its proprietary one. This task belongs not just to religion but to philosophy and psychology, as Jonathan Haidt's (2013) The Righteous Mind: Why Good People are Divided by Politics and Religion amply demonstrates. Gould has given us no reason to think that religion can do it better.

The positive message of NOMA is that science and religion are not enemies between which we have to choose. Yes, there are some members of the family of religions who turn their back on science in favor of their own teachings, but equally there are other members who see no such conflict. The problem with religion is not its relation to science, but the conflict between the followers of one religion and the followers of another. A familiar example is the status of Jesus Christ. While the Christian tradition revers him as God Incarnate or the son of God, Moslems regard him as only one of the prophets, and neither the latest nor the greatest, and Jews see him as a tragic figure within their own fold. Surely these different views can't all be true, but it is hard to see how the family of religions has the resources to sort out such conflicts, or the readiness to turn the issue over to a third party. For all practical purposes, the issue is intractable.

Theologians and philosophers of religion are aware of the problem of conflicting truth-claims, of course, but it is doubtful whether they have a good solution. John Hick, who repeatedly returned to the problem, outlines three possible approaches: exclusivism, inclusivism, and pluralism (Hick, 1963). The exclusivist favors his own religion: any competitor must be a false religion. The inclusivist may favor his own religious faith but he is prepared to grant the same privilege to followers of other faiths, like the native speaker who prefers his own language but admits that native speakers of other languages are entitled to the same privilege with regard to their own. The pluralist tends to regard existing religions as historical and cultural expressions of a transcendent reality: different names, you might say, for the same God.

None of these positions solves the problem. Exclusivists can be found in every religious tradition, refreshing the conflict, not resolving it. Inclusivism tends to collapse into relativism: the faith of culture $\mathrm{X}$ is true for members of $\mathrm{X}$, just as 
the faith of culture $\mathrm{Y}$ is true for members of $\mathrm{Y}$, regardless of whether these faiths are compatible. In doing so, the relativist conflates "true for X" with "accepted as true by X", which are not the same. Columbus accepted as true the belief that he could reach the Indies directly by sailing west, but his belief was not true. Two continents stood in his way.

The pluralist is for high-minded folks, who look on religion differently than do their low-minded brethren who take their gods for the real thing, not its simulacra. It is easier to worship Jesus as God Incarnate than as Jesus the stand-in for a God beyond reach. Hick has done a service by high-lighting different attitudes toward religion, but strangely he seems to leave out of account another trinity-skepticism, indifference, and hostility. Nevertheless, his magnum opus, An Interpretation of Religion (Hick, 1989), is a refined and eloquent statement of his late account of pluralism.

\section{Conclusion}

Familiar as disagreement and controversy are in religion, they are not absent from science either, as demonstrated by the history of science. Such disagreement can be found even in current science. For example, while the theory of evolution is at the heart of modern biology, biologists sometimes disagree about the details of how evolution works. Stephen Jay Gould himself proposed a theory of punctuated equilibrium, according to which evolution proceeds by periods of relative stability which are disrupted by cataclysmic events like the asteroid which struck the earth about sixty-five million years ago, bringing about the end of the age of dinosaurs and the beginning of the ascendancy of mammals. Gould also proposed that some features of organisms living today, like language and art, are "spandrels" - incidental features like the pictures between the arches of a cathedral-rather than the result of adaptations, in contrast to other evolutionists who continue to emphasize the adaptive value of such features.

Despite this kind of disagreement, however, the history of science gives us no reason to think that such disagreements are intractable. The readiness of scientists to look for new evidence, to put accepted theories to test, to amend or abandon them if necessary, to seek consensus by reviewing each other's results, acts over time as a brake to the development of intractable disagreement at a fundamental level. This is the respect in which science seems most different from religion. Scientists have developed a discipline which allows for disagreement and its eventual resolution, whereas their counterparts in religion-theologians-have yet to develop a discipline which allows for the resolution of fundamental disagreement. Recognizing the shortcomings of human cognitive abilities and the need for safeguards, science is prepared to be self-correcting in a way that religion is not. That may be the principal difference between the two magisteria.

\section{Conflicts of Interest}

The author declares no conflicts of interest regarding the publication of this paper. 


\section{References}

Andre, S. (1993). Was Hume an Atheist? Hume Studies, XIX, No. 1.

Collins, F. S. (2006). The Language of God: A Scientist Presents Evidence for Belief. New York: Free Press.

Darwin, C. (1857) Darwin on Splitters and Lumpers. Letter to Joseph Dalton Hooker in 1857.

Dawkins, R. (2006). The God Delusion. Boston, MA: Houghton Mifflin.

Dennett, D. (2006). Breaking the Spell: Religion as a Natural Phenomenon. New York: Penguin Books.

Descartes, R. (1641, 1984a). Meditations on First Philosophy. In J. Cottingham, et al. (Eds.), The Philosophical Writings of Rene Descartes (Vol. I, pp. 111-151). Cambridge: Cambridge University Press.

Diamond, J. (2012). What Can We Learn from Traditional Societies? (p. 340). New York: Viking Press.

Dworkin, R. (2011). Justice for Hedgehogs. Boston, MA: Belknap Press of Harvard University. https://doi.org/10.2307/j.ctvjf9vkt

Edwards, P. (1967). The Encyclopedia of Philosophy (8 vols. in 4). New York: Macmillan.

Einstein, A. (1941). Religion and Science. A Symposium Published by the Conference on Science, Philosophy and Religion in their Relation to the Democratic Way of Life, Inc., New York: The Symposium.

Fielding, H. (1749, 1980). A History of Tom Jones, a Foundling. Oxford Dictionary of Quotations (3rd ed.) Oxford: Oxford University Press.

Gould, S. J. (1999). Rocks of Ages: Science and Religion in the Fullness of Life. New York: Ballantine Publishing Group.

Haidt, J. (2013). The Righteous Mind: Why Good People Are Divided by Politics and Religion. New York: Vintage Books.

Harris, S. (2004). The End of Faith: Religion, Terror, and the Future of Reason. New York: Norton.

Hearnshaw, J. B. (2010). Auguste Comte's Blunder: An Account of the First Century of Stellar Spectroscopy and How It Took One Hundred Years to Prove That Comte Was Wrong.

Hempel, C. G. (1988). Science and Human Values. In E. D. Klemke, R. Hollinger, \& A. D. Kline (Revised Ed. Eds.), Introductory Readings in the Philosophy of Science (pp. 334-348). Buffalo: Prometheus Books.

Hick, J. (1963). Philosophy of Religion. London: Prentice-Hall.

Hick, J. (1989). An Interpretation of Religion. Newhaven, CT: Yale University Press. https://doi.org/10.1057/9780230371286

Hitchens, C. (2007). God Is Not Great: How Religion Poisons Everything. New York: Hatchette Book Group.

Hume, D. (1739-1740, 2006). A Treatise of Human Nature. Ed. with Intro by Ernest C. Mosner. London: Penguin Books. https://doi.org/10.1093/oseo/instance.00046221

Hume, D. (1748). An Enquiry Concerning the Human Understanding. In E. A. Burtt (Ed.), The English Philosophers from Bacon to Mill. The Modern Library. New York: Random House.

Russell, B. (2019). Logical Constructions. Stanford Encyclopedia of Philosophy. https://plato.stanford.edu/entries/logical-construction/ 
Santayana, G. (1923, 1955). Scepticism and Animal Faith. New York: Dover Publications.

Shirer, W. (1960). The Rise and Fall of the Third Reich. New York: Simon \& Schuster.

Smart, N. (1989). The World's Religions. Cambridge: Cambridge University Press.

Smith, H. (1958). The Religions of Man. Reissued with Changes as The World's Religions, 1991. New York: Barnes \& Noble.

Tillich, P. (1957, 2001). Dynamics of Faith. New York: Harper Collins.

Weinberg, S. (1999, 2001). A Designer Universe? In Facing Up: Science and Its Cultural Adversaries (pp. 230-242). Cambridge: Harvard University Press.

Wittgenstein, L. (1953). Philosophical Investigations (3rd ed., G. E. M. Anscombe, Trans.). New York: Macmillan. 